\title{
Meeting User Needs in the Modern Museum: Profiles of the New Museum Information Professional
}

Paul F. Marty

College of Information

Florida State University

marty@ci.fsu.edu

\begin{abstract}
This article presents results from twenty-one semi-structured interviews with museum information professionals who were asked about their experiences working with information resources, tools, and technologies. These interviews were analyzed to develop profiles of four types of information professionals working in museums. The article presents these profiles, focusing on the responsibilities of today's museum information professionals and their role in meeting user needs in the modern museum, thereby improving understanding of the evolving role of museum information professionals.
\end{abstract}

\section{Keywords}

Museum informatics; museum information professionals; meeting user needs.

\section{Notice}

This is the author's version of a work that was accepted for publication in Library \& Information Science Research. Changes resulting from the publishing process, such as peer review, editing, corrections, structural formatting, and other quality control mechanisms may not be reflected in this document. Changes may have been made to this work since it was submitted for publication. A definitive version was subsequently published in Library \& Information Science Research, 28 (1), 128-144. http://dx.doi.org/10.1016/j.lisr.2005.11.006 


\section{Introduction}

There is a growing sense among museum professionals that the skills taught in Library and Information Science (LIS) programs are increasingly relevant to their everyday needs. While information management skills have always been important to museums (Lord \& Lord, 1997; Orna \& Pettitt, 1998), and certain museum employees (e.g., museum librarians and registrars) have frequently had LIS backgrounds (cf., Koot, 2001; Reed \& Sledge, 1988), a "new" museum information professional is evolving, one that is not easily defined, yet one that is tasked with solving a wide variety of information problems (Marty, 2004b; Marty, 2005).

The emergence of this new role has coincided with the growing belief that museum information resources should be as readily available as information resources are in most libraries. For some museum professionals, this can be quite a change in information policy; as Coburn and Baca (2004) describe, "museum information has a history of being hoarded if not outright hidden in curatorial files" (p.14). Recently, numerous museum consortia worldwide have developed initiatives to provide widespread access to museum information resources (Perkins, 2001).

Meeting the needs and expectations of the users of museum information resources can be difficult. Unaware of the historical barriers to information access that have separated libraries, museums, and archives, users expect equal and immediate access to all resources regardless of the type of organization (Rayward, 1998). While advances in information representation and digitization technologies are helping museum professionals meet user needs, tasks that are relatively simple in the LIS world remain significantly more problematic in museums (Marty, Rayward, \& Twidale, 2003).

\section{Problem Statement}

Against this backdrop, a new type of museum professional has emerged: the "museum information professional." Despite significant interest in this role (Coburn \& Baca, 2004; Grant, 2001; Hamma, 2004b; Hermann, 1997; Roberts, 2001), little is known about the nature of this position. Museum information professionals are among the least studied of all consumers and producers of museum resources (Gilliland-Swetland \& White, 2004). In particular, little is known about the roles they play in museums, how these roles have evolved over time, and what skills they need to fulfill their responsibilities.

To improve overall understanding of museum information professionals, this article addresses the following research questions: What is the role of information professionals in the museum? What do museum information professionals do on a daily basis? What problems do they face? How important are their positions to the modern museum? How have their roles and responsibilities evolved over time? How are their positions likely to change in the future?

To answer those questions, this article presents four profiles of modern museum information professionals, focusing on their responsibilities and skills, as well as the evolution of their positions over time. A careful study of the four profiles presented here will help the LIS community better understand the relative importance of information professionals in museums, the characteristics that enable them to do their jobs, and the strategies they use to meet user 
needs. This research is also intended to help museum researchers, administrators, and professionals come to terms with the changing roles of information professionals in museums.

\section{Literature Review}

Researchers interested in museums and information science have learned a great deal about traditional information-oriented positions in museums. Although the career path of the museum librarian or registrar might be less prestigious than that of a museum curator, these roles are welldocumented in most guides to museum careers (American Association of Museums, 1994; Burkaw, 1997; Danilov, 1994; Glaser \& Zentou, 1996; Schwarzer, 2001a). Detailed analyses of the jobs of museum registrars (Case, 1988) and museum librarians (Reed \& Sledge, 1988) are readily available.

Over the past decade, museum professionals have become increasingly concerned with meeting user needs, ensuring that museum information resources are available to all users as needed (Marty, Rayward, \& Twidale, 2003). Employees at a growing number of museums are learning about metadata schemas and controlled vocabularies (Bearman, 1994; Lanzi, 1998), distributed collection building and data sharing initiatives (Allen, 2000; Bennett \& Sandore, 2001; Rinehart, 2001), and information policy and digital rights management (Bearman, 1997; Blackaby, 1997; Carson, 2001; Zorich, 1999). The growing expectation that museums will employ individuals with such skills has made the "new" museum information professional very important.

But what exactly is the "new" museum information professional? In some sense, all museum professionals can be considered information professionals; nearly all deal with some aspect of museum information resources on a daily basis, even those not specifically trained as museum librarians or registrars (cf., Orna \& Pettitt, 1998). Yet the challenges of museum informatics are not the same challenges as those posed by either museum librarianship or museum registration, and while there are considerable areas of overlap, museum informatics is a unique field of study requiring its own, substantially different, educational background and career path (Marty, 2005).

In the mid 1990s, Glaser and Zenetou (1996) discussed the need for someone "responsible for facilitating the flow of information within an institution and between the institution and the public" (p.103). Likewise, Hermann (1997) described the "new role in museums for an 'information manager' who is charged with caring for the museum's information" (p.75). Today, the success of museums in the information society depends largely on a new type of information professional, one specifically trained to deal with museum informatics issues, yet few museums are fortunate enough to have employees specifically trained for and dedicated to such positions.

The importance of this new role can be seen in the number of studies completed for the benefit of museum information professionals. Studies of the information needs, seeking, and behavior of the typical users of museum information resources explored how museum visitors use information technologies in museums (Economou, 1998; Evans \& Sterry, 1999; Galani \& Chalmers, 2002; Schwarzer, 2001b) as well as the needs, characteristics, and interests of visitors to museum Web sites (Chadwick \& Boverie, 1999; Goldman \& Schaller, 2004; Ockuly, 2003; Sarraf, 1999). Kravchyna and Hastings (2002) stressed the importance of understanding the 
information needs of users at all stages of the museum visit, including online access before and after physical museum visits.

Understanding the needs of museum visitors can help museum information professionals better serve their clientele (Muller, 2002; Teather \& Wilhelm, 1999; Zorich, 1997). Cameron (2003) studied how helping museum visitors conceptualize and use museum information resources can transform the way museum professionals build relationships with their users. Coburn and Baca (2004) looked at how different metadata schemas help or hinder users seeking collections data from museums. Hamma (2004a) examined the changing expectations for online museums engaged in outreach to many different audiences. Bowen and Filipinni-Fantoni (2004) explored different methods of targeting unique user needs through personalization and pervasive computing technologies both inside and outside the museum.

Museum information professionals need to evaluate the steps they are taking to meet the information needs of their users. Recent studies explored the value of methods such as usability analysis, user-centered design, or transaction log analysis for museum information professionals (Gillard \& Cranny-Francis, 2002; Harms \& Schweibenz, 2001; Hertzum, 1998). Dyson and Moran (2000) discussed the importance of creating accessible and usable information resources for online museum projects. Cunliffe, Kritou, and Tudhope (2001) explored different methods for determining whether museum Web sites meet user needs, and discussed the dangers of not evaluating museum Web sites for usability. Peacock (2002) discussed statistics and transaction $\log$ analysis for museum professionals interested in evaluating user satisfaction with museum Web sites.

Few studies focused on the characteristics of museum information professionals (Grant, 2001; Hamma, 2004b; Marty, 2004b; Roberts, 2001). Bernier and Bowen (2004) evaluated the information behaviors of museum professionals online, in particular their use of online discussion forums. Gilliland-Swetland and White (2004) studied the ability of museum information professionals to use metadata standards that provide access to the museum's information resources online. Haley Goldman and Haley Goldman (2005) explored Web development as a profession in museums, interviewing museum webmasters and asking about their work, their sources of inspiration, and their ideas about the future of museum Web site design. Despite these valuable contributions, knowledge of museum information professionals pales in comparison to knowledge of the users they are trying to reach.

This lack of data about museum information professionals is disturbing, especially given the increasing importance of this role to the museum. As technologies change, and individuals adapt their work practices to coincide with new technologies, the responsibilities of the information professional in the museum are constantly evolving, making it difficult to nail down exactly what museum information professionals do (Marty, 2004b). A new role is emerging in museums that is difficult to define, constantly evolving, yet dramatically increasing in importance. It is important to understand the role of information professionals in the museum, how that role has changed over time, and how that role may evolve in the future. 


\section{Procedures}

Semi-structured interviews were conducted with 21 information professionals working in museums, asking them about the information resources, tools and technologies they use daily on the job. Research participants were recruited from various national and international museum conferences where attendees are interested in the role of information professionals working in museums. Given the lack of any existing registry for museum information professionals, it was determined that advertising this study at conferences likely to appeal to such individuals was the best way to locate and recruit potential participants.

Research participants worked at 17 different museums, including cultural heritage, science and technology, art, natural history and children's museums. Although they varied widely in technical skills and expertise, all research participants were responsible for managing information resources, tools, or technologies in a museum in some fashion. They ranged from relatively lower-level positions to middle-managers to high-level administrators in their respective museums, having anywhere from one to 30 years of experience in the museum field. They came from diverse backgrounds and held a wide variety of jobs, including positions with more traditional titles (e.g., curators, educators, or managers) as well as positions with more modern, technology-oriented titles (e.g., webmasters, new media specialists, and chief information officers). To concentrate on newly emerging roles of museum information professionals, individuals working specifically as registrars or librarians in museums were not interviewed.

Participants were asked several questions during their interviews about what they do on a daily basis, what skills they need to perform their jobs, and how these skills have changed over time. These questions included:

- How long have you worked in the museum field? How long have you worked at your current position? What is your current job title and job description?

- Please describe for me a recent project you worked on? Is this a typical representation of what you do on a daily basis? Could you tell me a bit more about your daily activities?

- What skills would you say you need in order to perform your job well? Have these changed over time? How so?

Interviews lasted approximately one hour each, and were transcribed completely and analyzed using grounded theory methodologies. Drawing upon the participants' answers to each of the above questions, a process of coding and memoing, as outlined by Strauss and Corbin (1998), was used to develop an understanding of the skills and responsibilities of information professionals working in museums. This kind of analysis is an iterative, on-going process where participant responses are analyzed as part of a continual process of exploring the data to identify emergent themes and dimensions. A random selection of the data was also examined, using the final list of concept codes, by a second researcher. From this analysis of the past and present experiences of information professionals currently working in museums, detailed profiles of the role of the museum information professional were developed, including information about the importance of these roles to museums and how those roles are changing over time. 


\section{Results}

From the analysis of these data, four profiles that describe the roles and responsibilities of different types of information professionals working in museums were developed: the Information and Communication Technologies (ICT) Specialist, the Webmaster, the Information Resource Manager, and the Chief Information Officer. These profiles do not represent one-toone relationships between interview participants and possible roles; of the twenty-one museum professionals interviewed for this study, no one participant fit exactly into only one profile. This was especially the case in small museums, where museum information professionals might be expected to perform many different functions as part of their daily job responsibilities, frequently crossing boundaries between all four of these profiles.

\subsection{The Information and Communication Technologies (ICT) Specialist}

The ICT specialist is a fairly common position for most museums. Even museums unable to afford full time help with their information and communication technologies usually rely on at least some part time help to keep their ICTs functioning; larger museums with more ICTs may naturally need to employ a larger number of these individuals. Of the participants interviewed for this study, four primarily identified themselves as ICT Specialists, and four remaining participants spent at least part of their time performing responsibilities associated with this profile.

In general, the ICT Specialist in the museum maintains the museum's computer hardware, multimedia equipment, and networking systems, and provides support for computer software running the gamut from web-enabled database systems to email clients. While they may have responsibilities tied to particular projects (e.g. creating databases for special needs), their day-today activities tend to revolve around "little things" such as maintenance, trouble-shooting, or solving any of the miscellaneous problems that occur on a daily basis in any organization. As one research participant put it:

Somebody can't figure out how to do a specific thing in Excel or Word, or you know they messed up something in their file and they need some help fixing it. There are a lot of little things like that. Larger projects don't happen as often; they happen occasionally. I think more of the day to day basis is a lot of the little coaching things; you know, people aren't quite sure how to fix something that they messed up or how to proceed on something, they're stuck. [P11]

Given the rapidity with which museums have incorporated ICTs into their everyday operations, having ICT specialists on staff is valuable for museums. Museum employees rely on these individuals to provide technical support services, by answering questions and solving problems affecting the entire museum. Not having anyone with those skills available can mean many wasted hours for museum professionals dependent on digital collections information systems and computer networks to perform their jobs:

You need someone in-house who knows how to fix things, you know, everything from software programming, to when the server needs to be restarted, and how do you restart 
the server, and someone just needs to be able to go in behind the scenes, so to speak, and configure things for institutions to use and to fix things when they break down, because they do, and [...] you need someone there that it doesn't take, you know, four thousand hours for them to do something because that's their field of expertise, to be able to solve these things and figure out how to use them. [P02]

As the museum grows and its ICT needs become more complicated, it can be difficult for the museum's ICT specialists to keep up with their responsibilities. As museum professionals explore new ways of meeting the needs of diverse audiences, the duties of ICT specialists tend to evolve far beyond solving simple technology problems or providing straightforward technical support. Increased expectations and new demands can result in ICT specialists feeling overworked, understaffed, and pulled in many different directions:

We have an IT department of three people for a staff of 250. Consequently, all of us do everything. That means the gamut from making sure the servers get backed up at night to applications development to digital imaging to brainstorming about integration of information across the museum. [P09]

What makes this situation especially difficult for some ICT specialists is the challenge of transitioning from dealing solely with the museum's technologies to dealing with the people who use those technologies, inside and outside the museum. As supporting the technology stops being the primary goal of ICT specialists, they find themselves working more frequently with people to identify new ways technologies can meet user needs. Tasks like requirements capture, information needs assessment, or user evaluations can be much more challenging than working with the mechanics of information and communication technologies:

You need to be able to receive the requirements given to you and be able to query and find out in more detail what the real requirements are. A lot of time people think they are telling you what they need, but you need to be able to probe it to find out really what's underneath that. I think the requirements gathering for specific needs is the most challenging part of any information job, because you need to be able to gather that sufficiently, otherwise you can end up creating something meeting the wrong need or not meeting the need at all. [P11]

\subsection{The Webmaster}

The increasingly-common position of museum webmaster continues to grow in importance for most museums; at the same time, the webmaster's responsibilities have changed dramatically, with duties that go far beyond simply marking-up pages in HTML (Marty, 2004a). Of the research participants interviewed in this study, nine specifically identified themselves as museum webmasters, and six of the remaining participants mentioned "webmaster responsibilities" as a primary part of their daily activities.

The museum webmaster is responsible for maintaining the museum's presence on the worldwide web, which includes technical considerations (e.g., installing servers or software), interface design questions (e.g., page layout or usability analysis), and social issues (e.g., assessing and 
meeting the information needs of the museum Web site visitors). The following quote shows that the museum webmaster does much more than create Web pages:

I am the technical authority for the museum in matters of the Web site and the materials that go up on the Web. I do some Web production myself, and help others in the museum to do Web production in house. I oversee contractors who we pay to do Web production for us. [...] Part of the job is more of a content manager to help to work with the staff of the museum to develop the perfect content for the Web site, and kind of decide what that is. $[\mathrm{P} 16]$

As the number of museums online has increased, the position of museum webmaster has become very important (Bowen, 1999). Whereas only a few years ago, many museum professionals may have been hard-pressed to figure out what to do with their Web site, today it is hard to find a museum activity (from education to registration) that cannot be incorporated somehow into the museum's online presence. With the Web frequently involved in everything museum professionals do, the museum webmaster, likewise, is involved in most museum projects. The unavoidable result is an increasing workload for most museum webmasters:

Five years ago we went around looking for people to put things on the Web site, now we have a list that reaches out almost a year with people with requests for the Web site. [...] [Back then] the time horizon for a new project was about two weeks. Now we're looking at about a year. If you came to me with a brand new idea, and we thought it was a perfectly good idea, we might get to it in a year. [P07]

As online access and Internet use become more integrated into museum activities, the responsibilities of the museum webmaster become more elaborate. For users outside the museum, Web sites have become more dynamic, offering online visitors the opportunity to interact with museum collections in real time, and removing barriers that traditionally kept behind-the-scenes activities from the museum's visitors (cf., Sayre, 2000). For users inside the museum, Web sites are more frequently relied upon for sharing information resources and tracking museum projects. Museum webmasters are now responsible for maintaining intranets for museum employees in addition to a traditional Web site for the museum's visitors. Over the past few years, museum webmasters have found themselves being slowly integrated into all aspects of museum operations, with ever-increasing and increasingly-varied responsibilities:

As webmaster I have to manage the flow of information from server to workstation, managing and coordinating the review policies and review committees. I also have to do some development for our museum systems. I have to manage our collections information system as it relates to approved Web data from that system. I have to pay attention to administrative tasks, security rules set forth [by the IT office], and I have to do periodic system administration on servers. I have to test products, review products. I sit on several working groups for product assessment [such as] digital asset management systems, Web content management systems, collections information systems, and those sorts of things. [P21] 
These changes and new responsibilities have brought new challenges to the webmaster. No longer able to work alone in some back office, museum webmasters must shift their focus from inherent self-sufficiency to working with the correct people at the correct time. Adapting to new approaches to Web design, such as dynamic content management, takes time and can be difficult. Among other things, these new responsibilities require a change in "attitude:"

We really thought in terms of HTML in the beginning, very simple Web pages that didn't involve any scripting. They weren't really relying on dynamic content. We've really stretched that to the point where that same medium is really behaving more like a set of applications. It's gotten far more complex. That was around before, but what needed to happen was an attitude shift. We really needed to start thinking about how can we make this medium really serve the needs of the entire staff. [P07]

\subsection{The Information Resource Manager}

As museums integrate information resources and information technologies into all aspects of museum operations, there is a need for someone to manage these resources, not only from a technical perspective, but from an operational one. Of the participants interviewed in this research, six considered their primary responsibilities to involve facilitating the flow of information through the museum. As the official job titles of these participants were each unique, the generic term "information resource manager" was chosen to identify this type of museum information professional. In addition, four of the remaining participants spent at least some of their time performing responsibilities associated with this profile.

The information resource manager in the museum plays an important role in making sure the right information gets to the right people at the right time, whether they are located inside or outside the museum. While not necessarily in a position requiring advanced information technology skills, information resource managers often work with individuals who have more technical responsibilities. They frequently work as negotiators, trying to figure out what is best for the museum, while simultaneously exploring all possible options:

My whole job is basically deciding what to put on the net and how to put it on the net. I don't do the programming. We subcontract the programmers, and I call the programmers, and say, 'Can you make it do this?', and they say, 'Yes', and I say, 'Well, can you make it do that?', and they say 'No, but we can make it do this instead.' [P02]

It is important that these types of negotiations be performed by someone able to make decisions about the technical or information-oriented directions the museum will be taking in the future. Not only will they need the authority to make decisions affecting the museum's information policy, they will need to be sufficiently knowledgeable about the place of information science, information technology, and information management in the modern museum. Frequently, this will not mean that information resource managers know the answers to their questions in advance, but that they have the ability to ask the right questions: 
We do a lot of work with contractors, and we hire them because we are confident of their abilities. It's more a matter of knowing enough that you're asking the right questions, rather than not trusting somebody to give you the answers. [P01]

This is also a difficult position for museum information professionals, because it means they need to keep up with the changing needs and expectations of the museum's users, from the elementary school student accessing a multimedia kiosk in the museum's galleries to the academic researcher accessing the museum's online databases. The information resource manager needs to ensure that the information resources, tools, and technologies used at the museum are specifically suited to meet users' needs and expectations as they change over time. Doing this well does not necessarily require good technical skills; instead, it requires the ability to monitor a constantly changing landscape of information practices, policies, and technologies from multiple perspectives with an eye to what will be most useful in the future:

No one is depending on me to know the latest version of anything. If I need to know the latest version of Photoshop or whatever, I ask somebody on my team who already knows how to do that. The only thing that I do keep an eye out [...] to see what's going on with different kinds of technologies [...] like handhelds in the museum. I try to keep up to date with what's going on there because at some point, if that idea ever really does, if I do see a perfect connection between what that technology does and things we're trying to do, I would want to know who to go to and what kinds of expectations were or what are the requirements for producing something like that that people have. [P04]

The task of constantly monitoring the future value of different information resources or technologies can be stressful and difficult, especially since the information resource manager needs to consider (and sometimes predict) how users will use new information resources and technologies from their own perspectives. This can be hard to do, especially when one considers the many types of users that make up the museum's clientele. The ability to "look at things through other people's eyes" is especially valuable for the museum information resource manager:

One of the things that I could do was that I was looking at it through non-programmer eyes, I was very much closer to the user than I was to being a developer in my skills, and I think that was key. I could work with all of these different types of people, I could understand what the people who were concerned with the graphics were talking about, I could understand what the needs of the teachers and the kids were. [...] If you try to get a physicist to explain how an atomic bomb works, a second-grader's never going to be able to understand it, but if you can manage to get a layman to explain how an atomic bomb works, a second-grader can understand it, because they're going to be using much simpler words and much simpler tactics and things like that. [P02]

\subsection{The Chief Information Officer (CIO)}

The position of chief information officer (CIO) is an uncommon one in museums; usually only very large museums will have a specific individual with this title. Of the research participants interviewed, only two (both from large museums) identified themselves as chief information 
officers, although three of the remaining participants (all from small museums) describing having de facto $\mathrm{CIO}$ responsibilities for their museums.

Museum CIOs are responsible for setting diverse agendas and making wide-ranging information policy decisions about the implementation and use of information resources, tools, and technologies. While the information resource manager tends to work at a project level, the museum $\mathrm{CIO}$ is the authority for all questions about information science and technology in the museum; in this way, the CIO usually ranks just below the museum's director in terms of administrative authority and control:

I'm responsible or have managerial responsibility for the technology needs for the entire museum. That includes hardware, software, tech support, training, all aspects of computer-related activities and technology. [P18]

The position of CIO is important for museums, because the CIO ensures that the museum is achieving its mission from a museum informatics perspective. Supported by a large staff of ICT specialists, webmasters, and information resource managers, museum CIOs concern themselves with high-level questions about whether the use of information technologies and provision of information resources truly serve the needs of the museum's constituents:

My job is to develop the use of technology in any way that helps the productivity, costeffectiveness of the institution in achieving its mission. [P19]

As information technologies are integrated into all aspects of museum operations, the job of the $\mathrm{CIO}$ becomes more complicated. The successful museum CIO must adapt to constantly changing job requirements. Only in this way will he or she be able to consistently position the museum on the forefront of information technology development and use:

I am responsible for all aspects of information technology and its use. That ranges from telephone systems to networks to Web development to gallery interactives and installations and sometimes the technology use in galleries, all business and operational technical systems. In addition, I'm responsible for the long-range planning with respect to new technology, and also all technology strategic planning. And the museum has established a strategic goal of national leadership in the use of technology, so I'm responsible for seeing that that is achieved. [P19]

Being a museum CIO can be difficult; it is a demanding, time-consuming position with constantly changing job requirements. All users of museum information resources, inside or outside the museum, depend on the CIO having established proper information policies and strategies for information access. If the right information is not available at the right time and in the right place, museum CIOs have failed at their task of providing access to information:

I'm in charge of overseeing the technological spin on information in the museum, making sure that there is efficient access to that information, and that the staff needs as to information and technology are being met, and they have the tools they need to access the databases and other information sources and archives here at the museum. Also I'm in 
charge of making sure that these sources and resources are created so that people outside the museum, in the community and around, have access to similar materials so they can see what the museum's about, what we have here, so that we can help to educate our visitors and the public at large about the cultures and topics we're dealing with in the museum. [P05]

\section{Discussion}

Museums can no longer survive without the skills that museum information professionals possess. As Hamma (2004b, p.12) writes:

Adding information management as an integral part of a museum's routine activities will or should change the organization with the addition of at least some new staff, new skill sets and a new management effort. Even in a zero sum budget, the only choice involved is about how - not if - that change will be received and integrated into the organization's activities.

Museum researchers and practitioners have spent nearly a decade trying to identify the roles and responsibilities of "new" information professionals in museums. Despite this research, museum administrators still struggle to write job descriptions for database designers, information architects, and Web analysts that clearly specify the museum's changing needs with respect to these positions. Attempting to pin down the role of the new museum information professional is like chasing a moving target.

The profiles detailed above clarify the roles and responsibilities of museum information professionals currently working in modern museums. These profiles will be useful to museum administrators planning new hires, museum researchers exploring museum informatics, and museum studies students seeking jobs in the future. In particular, these profiles highlight the challenges faced by each type of museum information professional.

Museum ICT specialists face the challenge of understanding how or why ICTs are used by museum employees. Successfully completing advanced information technology projects in the museum means knowing more than how to use technology; it means knowing how to deal with people and their information needs. To meet user needs in the modern museum, the ICT specialist must be able to shift from a technology-centered to a user-centered focus.

Museum webmasters face the challenge of needing to focus more on the users of the museum's Web site than on the Web technologies themselves. Whether one looks at the external or internal users of the museum's information, the webmaster is frequently the museum's front line of defense: responsible for making sure that all users find the information they need when they need it. To ensure user needs are being met, the museum webmaster must be able to examine the museum's online offerings from a user-centered perspective.

Museum information resource managers face the challenge of finding out what the needs of the museum's users are, and working to ensure that those needs are met. The users of museum information resources, be they online visitors searching the museum's online collection 
databases or employees looking for important documents on the museum's intranet, frequently have no voice in the design, development, and implementation of the museum's information systems and technologies. The museum information resource manager is the user-centered mediator between the museum and its many different users with their diverse information needs.

Museum CIOs face the challenge of assessing user needs from a museum-wide perspective. They guide attempts to gather data about the needs of the museum's users, by running online surveys or interviewing museum visitors in the galleries. They make decisions about the nature of information resources to be provided to users, deal with resulting questions about the quality or quantity of those resources, and ensure that the museum's information-related activities stay aligned with the museum's overall mission and goals.

One final question remains: what do these profiles tell us about who the "new" museum information professional is? From comparing the roles and responsibilities of museum information professionals across all four of these profiles, there emerge three characteristics that describe the nature of the new museum information professional: crossing boundaries, assessing user needs, and serving as user advocates. These characteristics are related to the new museum information professional's ability to meet user needs in the modern museum, and it is these characteristics that cut across all four profiles.

\subsection{The New Museum Information Professional Crosses Boundaries}

It is difficult to specify definitive roles for museum information professionals that are capable of describing each individual perfectly. The profiles identified above do not specific obvious barriers that separate one profile from another. According to their skills, responsibilities, and abilities, all research participants overlapped at least slightly with two or more profiles. The first characteristic, then, that all museum information professionals share is their need to cross boundaries between different aspects of their jobs.

The concept of "boundary crossing" is aligned with the need for the new museum information professional to adapt to changing needs and expectations in the museum. For the research participants, the porous nature of the boundaries between these profiles reflected the way they frequently had to shift from role to role, and even job to job, within the museum. Nearly all participants commented on the need to shift responsibilities frequently to keep up with the changing expectations they face from users of the museum's information resources.

What causes such shifts in job responsibilities and requirements? From a practical perspective, one could argue that the need for museum information professionals who can learn new skills and cross boundaries between these four profiles stems from the different needs of different museums. Small museums without funds to hire more than one information professional need someone whose abilities cut across all four profiles; large museums will likely hire employees with diverse backgrounds and multiple skills and abilities. From a conceptual perspective, one can argue that the need to cross boundaries among all four profiles stems from the museum information professional's focus on assessing and meeting the information needs of many different types of users. 


\subsection{The New Museum Information Professional Assesses Information Needs}

Stressing information needs assessment as a focus for new museum information professionals may be a bit surprising. When considering the role of information professionals in museums, one might assume museum professionals would think primarily about the technical capabilities of these individuals. Information and communication technologies in museums are changing so rapidly that most museums remain desperate for employees who can guide them through the basic technology hazards of planning digitization projects, purchasing collections information systems, or joining online data sharing consortia. How museum information professionals use their abilities to help or hinder the museum's users accessing the museum's information resources, however, is more important than what technical skills they possess.

There is no question that specific technical skills are crucial (someone needs to be able to build web-enabled databases and museum websites), but information professionals in the modern museum need to employ their skills while working with users of the museum's resources to ensure that new technologies are meeting the users' needs. They need to look beyond their specific technical abilities, and see that it is not what they can do that is important, but how they do it from the users' perspective. Research participants frequently reflected on the need to view information technology as a means to an end, one that allows museums to reach their users by incorporating new technologies into different aspects of museum activities.

The second characteristic, then, that connects museum information professionals is a focus on assessing the needs of users with respect to the museum's information resources. If museums are to live up to their users' changing needs and expectations over time, someone in the museum needs to be responsible for tracking and evaluating the evolution of their information needs. The task of assessing information needs is not only shared across all four profiles of the new museum information professional, it is perhaps the most challenging aspect of the job.

\subsection{The New Museum Information Professional Serves as User Advocate}

The challenge of providing access to information in museums lies not with designing exhibits, building collections databases, or creating museum websites; it lies with ensuring that those information technologies are truly meeting the needs of the museum's visitors. To help museums keep up with changing expectations of museum users, the successful museum information professional will need to work closely with a broad spectrum of the museum's users, examining their information needs from multiple perspectives, and advocating those needs to appropriate individuals in the museum. This task will become increasingly important as museums become more focused on meeting the information needs of their users, and museum users demand more accountability from museum personnel.

By emphasizing the new museum information professionals' ability to serve as advocates for the users of museum information resources, this argument echoes the transformation of the museum to a more service-oriented information organization. If museums are to meet the changing needs of their users, someone in the museum must work as the users' advocate, approaching problems from a user-centered perspective. When user needs are not being met, the new museum 
information professional will likely be the museum staff member most attuned to the user's needs and best suited to argue the user's case.

The third characteristic, then, that all museum information professionals share is their ability to serve as user advocates, representing user needs within and without the museum. The new museum information professionals' abilities to cross boundaries within the museum and assess user needs from multiple perspectives means that they are the ones best positioned to ensure that the museum's information resources actually meet those needs. They serve as user-centered mediators between the museum and its users, advocating information needs for multiple users, and arguing for such issues as usability, open access, standardized data, and the availability of appropriate information resources to all users. They ensure, as much as humanly possible, that each user has a successful interaction with the museum's information resources.

\section{Conclusion}

While not every museum administrator will be able to afford to hire individuals dedicated to all or even just one of the four profiles discussed in this article, it is important that someone on staff at the museum has the ability to fill the position of the new museum information professional. The true value of this position lies not in the ability to design databases, develop Web sites, plan projects, or set information policy, but in the ability to meet user needs by crossing boundaries, assessing information needs, and serving as user advocates. As users evolve new expectations of what museums should provide, and as museum professionals evolve new ideas about bringing information resources to visitors, the new museum information professional will work to bridge these philosophies, drawing upon lessons learned from the LIS community to help museum professionals provide access to their information resources in ways that meet the changing needs and expectations of their users.

\section{Acknowledgements}

The author would like to acknowledge the hard work and dedication of the museum professionals who participated in this research. Without their contributions, this project would never have been possible. The author would also like to acknowledge the efforts of his research assistant, Anna Wilcoxon, who is a master's student in the College of Information, as well as the contributions of the anonymous reviewers who helped improve this manuscript.

\section{References}

Allen, N. (2000). Collaboration through the Colorado digitization project. First Monday, 5(6). Retrieved July 14, 2005, from http://www.firstmonday.org/issues/issue5_6/allen

American Association of Museums. (1994). Careers in museums: A variety of vocations. Washington, DC: American Association of Museums.

Bearman, D. (1994). Strategies for cultural heritage information standards in a networked world. Archives and Museum Informatics, 8, 93-106. 
Bearman, D. (1997). New economic models for administering cultural intellectual property. In K. Jones-Garmil (Ed.), The wired museum: Emerging technology and changing paradigms (pp. 231-266). Washington, D.C.: American Association of Museums.

Bennet, N., \& Sandore, B. (2001). The IMLS digital cultural heritage community project: A case study of tools for effective project management and collaboration. First Monday, 6(7). Retrieved July 14, 2005, from http://firstmonday.org/issues/issue6_7/bennett

Bernier, R. \& Bowen, J. (2004). Web-based discussion groups at stake: The profile of museum professionals online. Program: Electronic Library \& Information Systems, 38, 120-137.

Blackaby, J. (1997). Integrated information systems. In K. Jones-Garmil (Ed.), The wired museum: Emerging technology and changing paradigms (pp. 203-230). Washington, DC: American Association of Museums.

Bowen, J. (1999). Time for renovations: A survey of museum websites. In D. Bearman \& J. Trant (Eds.), Museums and the Web 1999 (pp. 163-174). Pittsburgh, PA: Archives and Museum Informatics.

Bowen, J., \& Filippini-Fantoni, S. (2004). Personalization and the Web from a museum perspective. In D. Bearman \& J. Trant (Eds.), Museums and the Web 2004 (pp. 63-78). Toronto, CA: Archives and Museum Informatics.

Burkaw, G. E. (1997). Introduction to museum work. Walnut Creek, CA: Altamira Press.

Cameron, F. (2003). Digital Futures I: Museum collections, digital technologies, and the cultural construction of knowledge. Curator, 46, 325-340.

Carson, C. (2001). Copyright and the Dead Sea Scrolls: A case study of the intellectual property issues involved in the research use of collections. Spectra, 28(3), 18-30.

Case, M. (Ed.). Registrars on record. Washington, DC: American Association of Museums.

Chadwick, J., \& Boverie, P. (1999). A survey of characteristics and patterns of behavior in visitors to a museum Web site. In D. Bearman \& J. Trant (Eds.), Museums and the Web 1999 (pp. 154-162). Pittsburgh, PA: Archives and Museum Informatics.

Coburn, E., \& Baca, M. (2004, June). Beyond the gallery walls: Tools and methods for leading end-users to collections information. Bulletin of the American Society for Information Science and Technology, 30(5), 14-19.

Cunliffe, D., Kritou, E., \& Tudhope, D. (2001). Usability evaluation for museum Web sites. Museum Management and Curatorship, 19, 229-252

Danilov, V.J. (1994). Museum careers and training: A professional guide. Westport, CT: Greenwood Press. 
Dyson, M. \& Moran, K. (2000). Informing the design of Web interfaces to museum collections. Museum Management and Curatorship, 18, 391-406.

Economou, M. (1998). The evaluation of museum multimedia applications: lessons from research. Museum Management and Curatorship, 17, 173-187

Evans, J., \& Sterry, P. (1999). Portable computers and interactive multimedia: A new paradigm for interpreting museum collections. Archives and Museum Informatics, 13, 113-126.

Galani, A., \& Chalmers, M. (2002). Can you see me? Exploring co-visiting between physical and virtual visitors. In D. Bearman \& J. Trant (Eds.), Museums and the Web 2002 (pp. 31-40). Pittsburgh, PA: Archives and Museum Informatics.

Gillard, P., \& Cranny-Francis, A. (2002). Evaluation for effective Web communication: An Australian example. Curator, 45, 35-49.

Gilliland-Swetland, A., \& White, L. (2004, June). Museum information professionals as providers and users of online resources. Bulletin of the American Society for Information Science and Technology, 30(5), 23-27.

Glaser, J.R., \& Zenetou, A.A. (1996). Museums: A place to work. Planning museum careers. London: Routledge.

Goldman, K.H., \& Schaller, D. (2004). Exploring motivational factors and visitor satisfaction in on-line museum visits. In D. Bearman \& J. Trant (Eds.), Museums and the Web 2004 (pp. 223-235). Toronto, CA: Archives and Museum Informatics.

Grant, A. (2001) 'Cataloguing is dead: Long live the cataloguers!' The changing role of museum information professionals in mediating museum knowledge. mda Information, 5(3), 1922.

Haley Goldman, M., \& Haley Goldman, K. Whither the Web: Professionalism and practices for the changing museum. In D. Bearman \& J. Trant (Eds.), Museums and the Web 2005 (n.p.). Toronto, CA: Archives and Museum Informatics.

Hamma, K. (2004a). The role of museums in online teaching, learning, and research. First Monday, 9(5). Retrieved July 14, 2005, from http://firstmonday.org/issues/issue9_5/hamma

Hamma, K. (2004b, June). Becoming digital. Bulletin of the American Society for Information Science and Technology, 30(5), 11-13.

Harms, I. \& Schweibenz, W. (2001). Evaluating the usability of a museum Web site. In D. Bearman \& J. Trant (Eds.), Museums and the Web 2001 (pp. 43-54). Pittsburgh, PA: Archives and Museum Informatics. 
Hermann, J. (1997). Shortcuts to Oz: Strategies and tactics for getting museums to the Emerald City. In K. Jones-Garmil (Ed.), The wired museum: Emerging technology and changing paradigms (pp. 65-91). Washington, D.C.: American Association of Museums.

Hertzum, M. (1998). A review of museum websites: In search of user-centered design. Archives and Museum Informatics, 12, 127-138.

Koot, G-J. (2001). Museum librarians as information strategists. INSPEL, 35, 248-258.

Kravchyna, V. \& Hastings, S. (2002). Informational value of museum Web sites. First Monday, 7(2). Retrieved July 14, 2005, from http://firstmonday.org/issues/issue7_2/kravchyna

Lanzi, E. (1998). Introduction to vocabularies: Enhancing access to cultural heritage information. Los Angeles, CA: Getty Trust Publications

Lord, B., \& Lord, G. D. (1997). The manual of museum management. Walnut Creek, CA: Altamira Press.

Marty, P. (2004a). The changing role of the museum webmaster: Past, present, and future. In D. Bearman \& J. Trant (Eds.), Museums and the Web 2004 (n.p.). Toronto, CA: Archives \& Museum Informatics.

Marty, P. (2004b, June). The evolving roles of information professionals in museums. Bulletin of the American Society for Information Science and Technology, 30(5), 20-23.

Marty, P. (2005). So you want to work in a museum? Guiding the careers of future information professionals in museums. Journal of Education for Library and Information Science, 46, 115-133.

Marty, P., Rayward, W.B., \& Twidale, M. (2003). Museum informatics. Annual Review of Information Science and Technology, 37, 259-294.

Muller, K. (2002). Museums and virtuality. Curator, 45, 21-33.

Ockuly, J. (2003). What clicks? An interim report on audience research. In D. Bearman \& J. Trant (Eds.), Museums and the Web 2003 (n.p.). Toronto, CA: Archives and Museum Informatics.

Orna, E., \& Pettitt, C. (1998) Information management in museums. Aldershot: Gower.

Peacock, D. (2002). Statistics, structures, and satisfied customers: Using Web log data to improve site performance. In D. Bearman \& J. Trant (Eds.), Museums and the Web 2002 (pp. 157-166). Pittsburgh, PA: Archives and Museum Informatics. 
Perkins, J. (2001). A new way of making cultural information resources visible on the Web: Museums and the open archive initiative. In D. Bearman \& J. Trant (Eds.), Museums and the Web 2001 (pp. 87-92). Pittsburgh, PA: Archives and Museum Informatics.

Rayward, W.B. (1998). Electronic information and the functional integration of libraries, museums and archives. In E. Higgs (Ed.), History and electronic artefacts (pp. 207-224). Oxford: Oxford University Press.

Reed, P.A., \& Sledge, J. (1988). Thinking about museum information. Library Trends, 37, 220231.

Rinehart, R. (2001). Museums and the online archive of California. Spectra, 29, 20-27.

Roberts, A. (2001). The changing role of information professionals in museums. $m d a$ Information, 5(3), 15-18.

Sarraf, S. (1999). A survey of museums on the web: Who uses museum websites? Curator, 42, 231-243.

Sayre, S. (2000). Sharing the experience: The building of a successful online/on-site exhibition. In D. Bearman \& J. Trant (Eds.), Museums and the Web 2000 (pp. 13-20). Pittsburgh, PA: Archives and Museum Informatics.

Schwarzer, M. (2001a). Graduate training in museum studies: What students need to know. Washington DC: American Association of Museums.

Schwarzer, M. (2001b, July/August). Art and gadgetry: The future of the museum visit. Museum News, 36-41.

Strauss, A., \& Corbin, J. (1998). Basics of qualitative research. Thousand Oaks, CA: Sage.

Teather, L., \& Wilhelm, K. (1999). Web musing: Evaluating museums on the Web from learning theory to methodology. In D. Bearman \& J. Trant (Eds.), Museums and the Web 1999 (pp. 131-143). Pittsburgh, PA: Archives and Museum Informatics.

Zorich, D. (1997). Beyond bitslag: Integrating museum resources on the Internet. In K. JonesGarmil (Ed.), The wired museum: Emerging technology and changing paradigms (pp. 171-202). Washington, DC: American Association of Museums.

Zorich, D. (1999). Introduction to managing digital assets: Options for cultural and educational organizations. Los Angeles, CA: Getty Trust Publications. 